\title{
The decline of the herpetofauna populations related to open water resources on Aegean islands using the example of Kythnos
}

\author{
Mario F. Broggi
}

Kirchstrasse 11, 9490 Vaduz, Liechtenstein; e-mail: mario.broggi@adon.li

\begin{abstract}
Though naturally rare, wetland biotopes on small Greek islands have great significance for biodiversity there and for migrating animals. Anthropogenic influences are diminishing these habitats, and climate change is accelerating their decline. This is exemplified for Kythnos with reference to the occurrence of the Balkan terrapin (Mauremys rivulata) and the Balkan frog (Pelophylax kurtmuelleri). The hydrologic catchments were searched for their occurrence in late May/early June 2021. Most of the former known populations have disappeared, and those that remain are extremely vulnerable, so that these species are likely to become extinct on Kythnos.
\end{abstract}

KEY WORDS Aegean islands; wetlands; Kythnos; Mauremys rivulata; Pelophylax kurtmuelleri; nature conservation aspects.

Received 19.07.2021; accepted 28.08.2021; published online 04.11.2021

\section{INTRODUCTION}

Wetland biotopes are rare on the Aegean islands, but they are important as a source of biodiversity and also as stepping stones for migratory species. They occupy isolated locations on the islands, and gene exchange is hardly possible for the populations living there. Annual levels of precipitation of $400 \mathrm{~mm}$ combined with long dry periods in the summer half-year create limiting conditions. On smaller islands especially, with correspondingly smaller hydrological catchments, wetlands are usually only present at certain individual locations and are small. They are relic sites from what were presumably more interconnected systems in the past in the time of the still forested islands.

The water-bound herpetofauna on the Aegean Islands includes the following common species: the green toad (Bufotes viridis), the Balkan frog (Pelo- phylax kurtmuelleri), the Balkan terrapin (Mauremys rivulata) and the grass snake (Natrix natrix).

In searching for possible habitats of such species on the islands, the focus is on the estuary areas of watercourses. As the water levels drop at the beginning of spring, the outflow of water into the sea is obstructed by barrier beach formations: the mouths of the watercourses are blocked by sand transported by coastal currents, thus impounding the outflow. These impounded water bodies may be very small but they can also resemble lagoons. They are partly covered by reeds and tamarisk and usually have a sandy bottom. They are important refugial areas for the waterbound herpetofauna, and function as stepping stones for migratory birds. There may also be prolonged water flow in streams with rocky beds, where the water remains longer due to lack of percolation, especially in plunge pools. Such sites are to be found in the middle and upper reaches of the streams. 
For their part, frogs and toads can adopt manufactured structures as habitats such as open cisterns and wells. Malkmus (1982) describes the importance of cisterns and wells as breeding sites for amphibians and water-related reptiles in the Mediterranean area. Roadside material extraction points can also retain water for some time if they have a clay content. Depressions created in the terrain to serve as watering places for livestock may also be relevant.

WWF Greece compiled an inventory of the Aegean islands in 2004-2007 (Catsadorakis \& Paragamian, 2007). The inventory was continued until 2015 and all data have been uploaded in WWF Greece's database (www.ygrotopio.gr). In total, 824 wetland structures have been listed on 77 island.

Among all these, there are 603 natural sites and 221 are artificial ones. They have a total area of about $107.85 \mathrm{~km}^{2}, 49 \mathrm{~km}^{2}$ of which are located on the large islands of Lesbos, Lemnos and Euboea. Most of these wetlands are to be found near the coast. More than $80 \%$ of them occupy an area of less than 8 hectares and they are considered small, according to the Greek legal framework (Law 3937, G.G.60/A/2011). Among these islands, 51 have between one to five wetland structures. Two objects were included for Kythnos, namely a wetland near Loutra (KYN 001) and one near Agios Stefanos (KYN 002).

We visited the island from 28 May to 8 June 2021. My colleagues Dr. Peter Goop (Vaduz, Liechtenstein) and Mag. Günter Stadler, Frastanz (Vorarlberg, Austria), assisted with the observations. Such excursions, mainly to Greek islands, have been conducted annually since 1972 . They have provided an insight into the flora and fauna of almost 60 Greek islands and especially the knowledge of their herpetofauna (Broggi, 2018).

\section{DISCUSSION}

\section{The natural conditions on Kythnos}

The island of Kythnos is located in the northwestern Aegean about $70 \mathrm{~km}$ from Athens. The island covers an area of just under $100 \mathrm{~km}^{2}$ and has 1500 inhabitants. The highest point on the island is $355 \mathrm{~m}$ a.s.l. Despite the relatively low altitude, the almost treeless island has a quite mountainous aspect. It has numerous small bays, some of them sandy, into which mostly small hydrological catchments of less than two $\mathrm{km}^{2}$ drain. With a dwindling population, large parts of the island are now only farmed extensively if at all. Traditional dry-stone walling is still a common feature of the landscape. Bushes of oleander (Nerium oleander) and the chaste tree (Vitex agnus-castus) thrive in the valley bottoms. They benefit from the moisture of the winter months. At the time of our visit, there was a severe drought on the island following low levels of winter rainfall, and no flowing water was to be seen.

\section{The herpetofauna of Kythnos}

In the past, herpetological excursions to Kythnos were conducted by Bird (1935), Werner (1935, 1938), Wettstein (1953), Clark (1968), Grillitsch \& Tiedemann (1984) and Cattaneo (1990), and the following species have been recorded: Balkan frog Pelophylax kurtmuelleri (Gayda, 1940), green toad Bufotes viridis (Laurenti, 1768), Balkan terrapin Mauremys rivulata (Valenciennes, 1833), Kotschy's gecko Mediodactylus kotschyi (Steindachner, 1870), Turkish gecko Hemidactylus turcicus (Linnaeus, 1758), Erhard's wall lizard Podarcis erhardii (Bedriaga, 1882), Balkan green lizard Lacerta trilineata Bedriaga, 1886, Dahl`s whip snake Platyceps najadum (Eichwald, 1831), Caspian whip snake Dolichophis caspius (Gmelin, 1789), leopard snake Zamenis situla (Linnaeus, 1758), and cat snake Telescopus fallax (Fleischmann, 1831). The most recent report was of the ocellated skink Chalcides ocellatus (Forsskål, 1775) (Itescu et al., 2016), which we encountered on taking our first step out of the apartment in Merichas on 29 May 2021, thus confirming this new find. The skink was found once more in nearby Martinakia Bay under a piece of formwork.

During our visit to the island, no snake species other than the Caspian whip snake were observed. The green toad (Bufotes viridis) also eluded observation, as no suitable water bodies for spawning remained and any tadpoles had already metamorphosed. In our survey, we concentrated on occurrences of the Balkan frog and the Balkan terrapin, searching the larger hydrological catchments and checking the previously reported sites (Fig. 1). 
We also visited the two wetland objects included in the WWF inventory and consulted the Google map of Kythnos for other potential sites.

\section{On Mauremys rivulata and Pelophylax kurtmuelleri}

\section{Balkan Terrapin, Mauremys rivulata}

To date the Balkan terrapin has been reported for 29 Greek and two Turkish islands in the Aegean (Broggi, 2012; Grano \& Cattaneo, 2017). The author's own observations have frequently confirmed its occurrence in the Aegean. Almost all of the reports relate to islands with an area of more than 50 $\mathrm{km}^{2}$. This is understandable, as the presence of surface waters normally implies a land mass of some size. The Balkan terrapin is the only species of the Aegean herpetofauna whose distribution does not correspond to the geological excavation system in the Aegean, as it is able to survive in saltwater for a certain length of time (Lymberakis \& Poulakakis, 2010). The optimum habitats of this turtle are the estuaries of flowing waters, e.g. lagoons, where they also colonize brackish water. In contrast to the European pond turtle Emys orbicularis (Linnaeus, 1758), it may also occur in eutrophic waters, i.e. over-fertilized. Under Greek law the Balkan terrapin is a protected species, also in the European Union is classified in Annexes II and IV of the Habitat Directives. It is also included in Appendix II of the Bern Convention.

Grillitsch \& Tiedemann (1984) provide a historical overview of reports on the occurrence of $M$. rivulata on the island of Kythnos. Werner (1938) and Wettstein (1953) in the lagoon near Loutra found it. Grillitsch \& Tiedemann (1984) added another observation on a road across a stream $2 \mathrm{~km}$ from Merichas in the direction of Dryopida on 1 May 1980. Peter Keymar (pers. comm.) confirmed the occurrence in the swampy delta of Loutra mentioned above in Grillitsch \& Tiedemann (1984) with an observation made in August 1977. Augusto Cattaneo (communication pers. 21 February 2020), who was working on the island's snake fauna (Cattaneo, 1990), reported a find made in May 1988 at the mouth of the stream in Episkopi Bay. That makes three documented occurrences of $M$. rivulata on Kythnos in the 20th century. The largest population, in a habitat covering 4.11 ha according to the
WWF's 2007 wetland inventory, was found in the lagoon with brackish water in Loutra Bay.

Our field trip in 2021 focused on the follow-up of the previous sites and clarification of further possibilities. On 30 May 2021, we found that the most important Loutra lagoon had ceased to exist. In this area there is now only a narrow concrete channel carrying a little over-fertilized water embedded in a larger excavated channel designed to cope with any major run-off in winter (Fig. 2). In the area of the former lagoon, there are stands of giant reed (Arundo donax). Under the conditions found, no $M$. rivulata populations can survive at this site. The second object in the inventory, also located on the east coast near Agios Stefanos, comprises the end of a wetted stream in its estuary area. The wet area

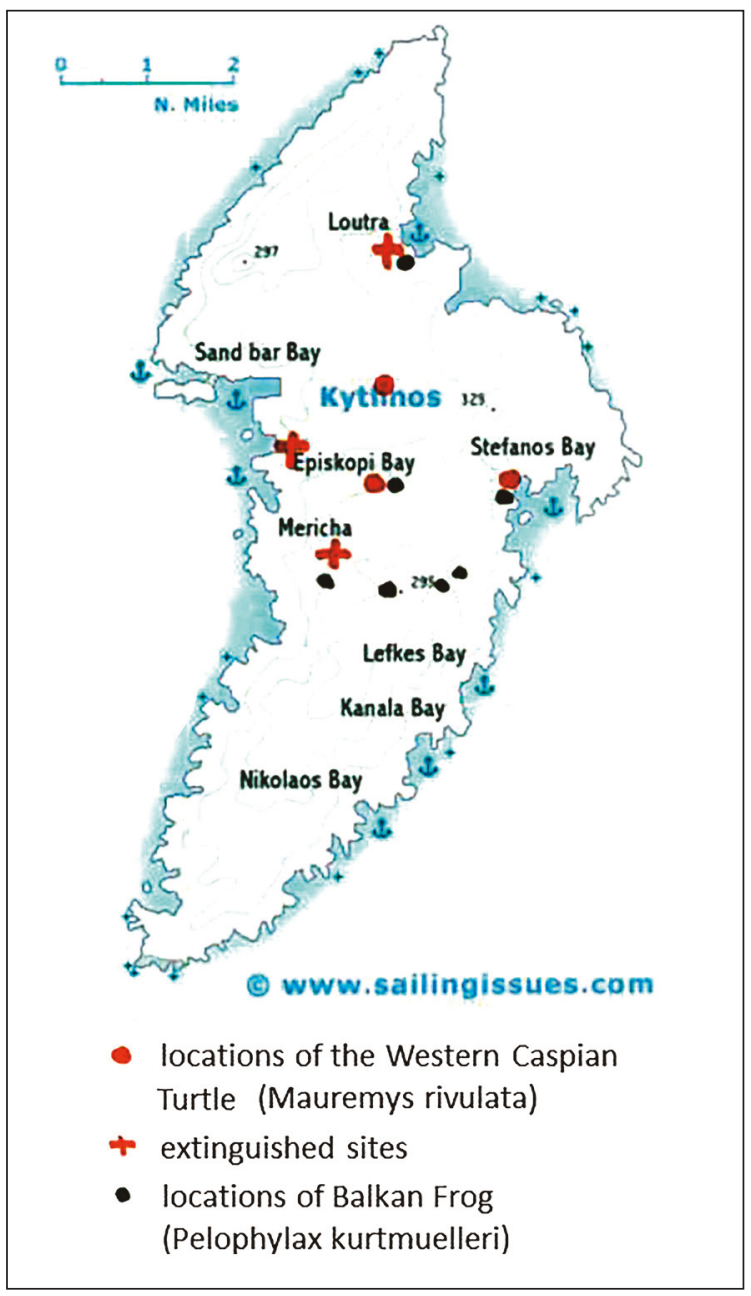

Figure 1. Locations of the Balkan Terrapin (Mauremys rivulata) and the Greek marsh frog (Pelophylax kurtmuelleri) on Kythnos. 


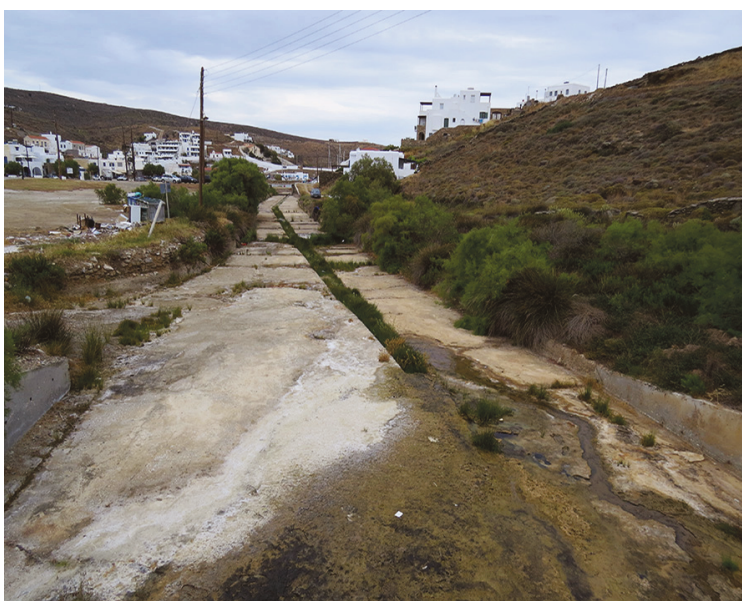

Figure 2. Loutra, former wetland with lagoon aspect of nowadays.

is about $20 \mathrm{~m}$ long and two $\mathrm{m}$ wide. On 30 May 2021, four turtles were seen here. A dirt road at the back of the sandy beach impounds the stream water. At this point, a membrane has been inserted as a seal to prevent further outflow. The tiny wetland has also been cordoned off with ropes. This is a clear indication of an awareness of the wetland's importance. This was the first record of Mauremys detection in 2021 with a small very vulnerable population. The other two earlier reports, for a stream west of Merichas according to Grillitsch \& Tiedemann (1984), and for the estuary area of Episkopi Bay according to Augusto Cattaneo, could not be confirmed on 30 May 2021. Both objects were completely dried out, and there are no natural indications of a suitable habitat. In addition, Episkopi Bay is now in the grip of tourism. The Episkopi stream itself has the largest hydrological catchment on the island. For this reason, a systematic search of the course of the stream was conducted on 1 June 2021. We received information about running water from Georgios Vadivoulis (www.experiencekythnos.gr), the son of our property owner in Merichas. He showed us a photograph taken on 28 April 2021 of a section of the stream that was still wetted. In a green valley about $2.5 \mathrm{~km}$ above the mouth of the stream (Fig. 3), we came across a stone placed in the otherwise dry bed of the stream to impound the water, which tailed back over a distance of 40-50 $\mathrm{m}$ and was being used for irrigation purposes. In the standing water $\left(37^{\circ} 23^{\prime} 787^{\prime \prime} \mathrm{N}, 24^{\circ} 25^{\prime} 540^{\prime \prime} \mathrm{E}\right)$, we observed three

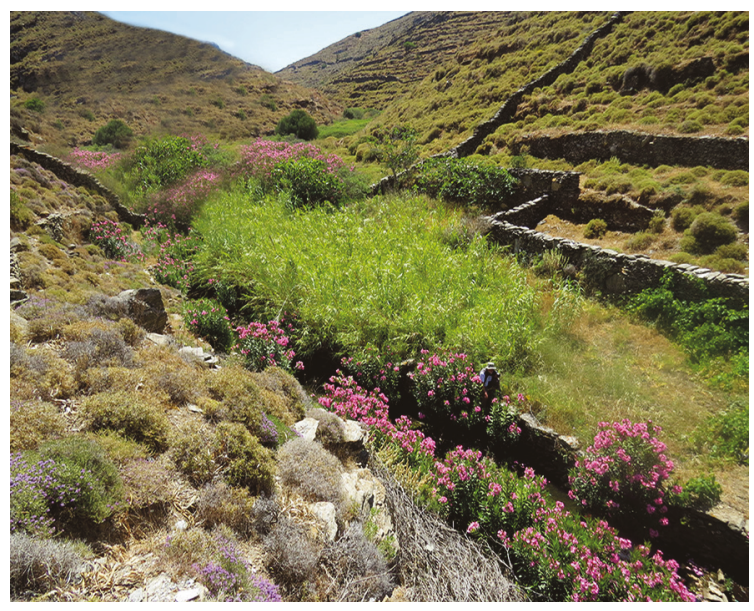

Figure 3. Episkopi brook $-2.5 \mathrm{~km}$ far away from the mouth of the stream.

adults, one semi-adult and one juvenile turtle. The Balkan terrapin is living by migrating up a stream towards the source area. Georgios Vadivoulis also informed us that turtles were said to occur in the Pyrgos area near Chora, near a former washhouse. Through persistent questioning however, we finally obtained information about a southern branch of the stream that leads to Apokrousi Bay, where untreated wastewater from Chora is discharged into the streambed downstream of a spring box. There, at 76 m a.s. $1 .\left(37^{\circ} 25^{\prime} 037^{\prime \prime} \mathrm{N}, 24^{\circ} 24^{\prime} 927^{\prime \prime}\right.$ E), a large number of turtles were found, probably more than fifty (Fig. 4). They seem to tolerate the wastewater, but no marsh frogs were observed. It is only thanks to this untreated wastewater that the turtle population survives here. Three recent occurrences of $M$. rivulata were thus recorded on Kythnos, while three earlier sites could no longer be confirmed. However all these occurrences are extremely vulnerable and hardly secures as habitats.

\section{Balkan frog, Pelophylax kurtmuelleri}

Grillitsch \& Tiedemann (1984) report observing the Balkan frogs in the stream between Merichas and Dryopida $1.5 \mathrm{~km}$ to the west of Merichas. They also found him in the swampy delta at Loutra. Neither sites have since been confirmed. On the other hand, the Balkan frogs was heard and seen in the above-mentioned backwater at Agios Stefanos on 29 May 2021. In Loutra, where the former lagoon has been destroyed, Balkan frogs were detected in 


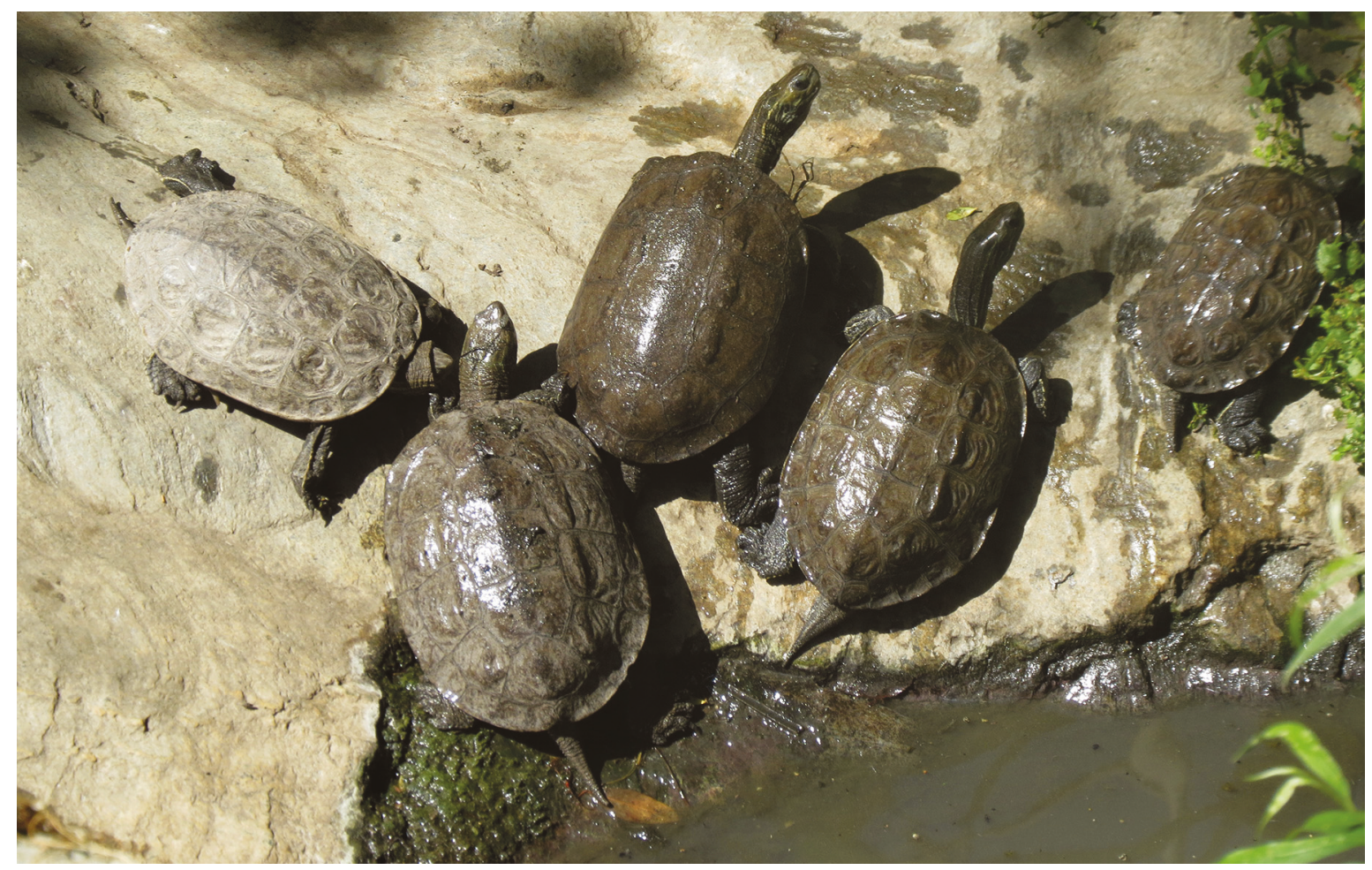

Figure 4. Balkan Terrapin in the stream leads to Apokrousi Bay in waste water of Chora.

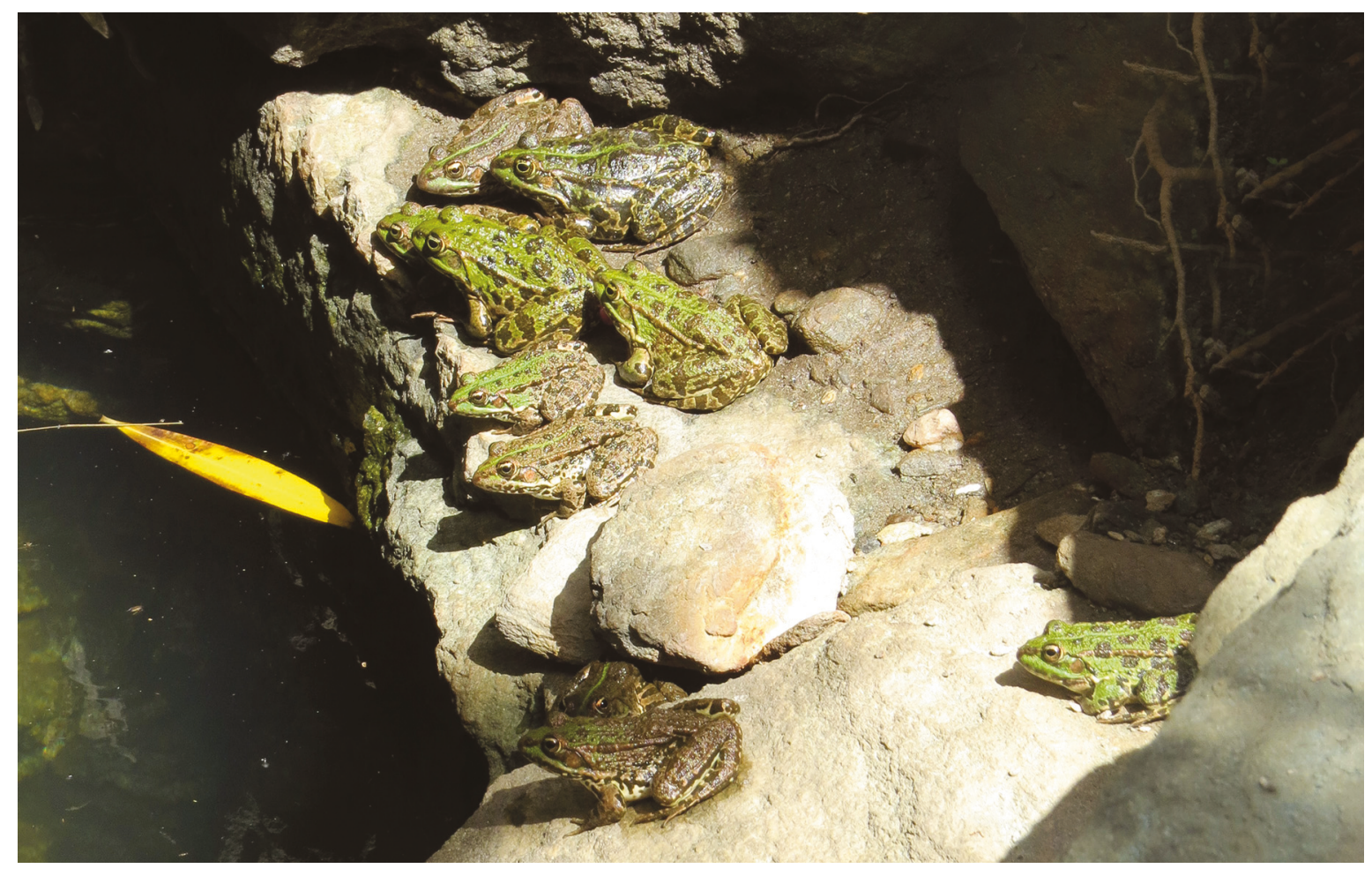

Figure 5. Open water well with Greek marsh frogs nearby the Konasmenou stream. 
the narrow over-fertilized wastewater channel on 30 May 2021. One day later, Balkan frogs were also observed in the impounded water of the Episkopi stream described above. In the Konasmenou stream, which drains to Merichas, Balkan frogs were discovered in two open wells and a residual pool two $\mathrm{km}$ from the mouth of the stream, just before it bifurcates (Fig. 5). These are micro-biotopes with an area of only about one square meter each. On 3 June 2021, the author heard the call of the Balkan frog from the valley near Dryopida. A search conducted the following day confirmed the presence of a residual pool with calling frogs in a side branch of the stream. Finally, on 4 June 2021, Balkan frogs were found by an old washhouse west of Dryopida, near the church of Panaghia stou Mathia. Within a meagre source area, they populated a small pond and an open cistern below the washhouse. Further, north, at Agios Ioannis Klydonas, Günter Stadler also came across Balkan frogs in a residual pool. That makes six extremely small localized occurrences on the island of Kythnos. All of these biotopes are highly vulnerable.

\section{CONCLUSIONS}

Mediterranean wetlands especially on islands are generally considered to be seriously threatened (Grillas et al., 2004). My observations based on decades are that the populations of amphibians and hydrophilous reptiles have noticeably declined due to the ongoing loss of wetlands. Since publication of the inventory of the island wetlands, WWF Greece has been working hard to protect the last wetlands in the Aegean. In their own assessment, around $60 \%$ of all island wetlands can be assumed to have disappeared since 1920 (WWF Greece, 2014). This was particularly evident from two visits to the island of Ikaria in 1986 and 2000 (Broggi, 2012), where the populations of the Balkan terrapin turtle have dwindled. For Sifnos and Syros, for example, there have been no recent sightings of the Balkan terrapin. On some islands, it has managed to migrate into the middle and upper reaches of watercourses. On running-water sites, the populations are generally smaller than in coastal locations. In the meantime, habitat loss continues. This takes the form of drainage of the last remaining wetlands, water extraction for irrigation purposes, and canal- ization of estuaries with land reclamation for agriculture and tourism, to name just a few examples of human land use to the detriment of these habitats. Spring boxes have been placed over the few springs, while the open wells that were originally built of undressed stones have been given a smooth coating of concrete, which prevents the passage of amphibians. Open cisterns are often no longer maintained and have been replaced by groundwater pumps. The resulting loss of habitats has led to the disappearance of the Balkan frogs on Tilos (Broggi, 2006). These threats are further compounded by the impacts of climate change. Giannakopoulos et al. (2011) predict a $15 \%$ decrease in winter precipitation.

The Greek authorities were made aware of the importance of the wetlands in a memorandum issued in 2009, resulting in a positive response for 74 objects on six islands, where corresponding provisions were made at the level of spatial planning. In a presidential decree published in June 2012, a protection order was finally issued for 380 wetlands on 59 islands. It is to be hoped that this decree will also be implemented and have the intended effect.

\section{ACKNOWLEDGEMENTS}

I would like to thank my longtime companions Dr. Peter Goop and Mag. Günter Stadler for their invaluable assistance during the research. I also thank Georgios Vadivoulis of Merichas, Kythnos (Greece) for the information provided on two populations of Mauremys and Thanos Giannakakis (WWF-Greece) for the information on the wetland inventory.

\section{REFERENCES}

Bird C.G., 1935. The reptiles and amphibians of the Cyclades. Annals and Magazine of Natural History, London, 16: 274-284.

Broggi M.F., 2018. Inselsehnsucht - 44 Reisen in den Mediterranraum mit Schwerpunkt Ägäis. Sonderdruck aus Berichte der Botanisch-Zoologischen Gesellschaft Liechtenstein-Sarganserland-Werdenberg, Band 40, $20 \mathrm{~S}$.

Broggi M.F., 2012. The Balkan Terrapin (Mauremys rivulata Valenciennes, 1833) in the Aegean Islands. Threats, nature conservation aspects and the situation 
on the island of Kea (Cyclades) as a case study (Testudines, Geoemydidae). Herpetozoa 24, (3/4): 149163.

Broggi M.F., 2006. Isolation und Landnutzungswandel und ihre Einflüsse auf die Herpetofauna dargestellt am Beispiel der Insel Tilos (Dodekanes, Griechenland). Herpetozoa, Vienna, 19: 13-16.

Catsadorakis G. \& Paragamian K., 2007. Inventory of the wetlands of the Aegean Islands, Identity, ecological status and threats, World Wide Fund for Nature, Athens, $392 \mathrm{pp}$.

Cattaneo A., 1990. I serpenti delle isole greche di Kythnos e Kea (Cicladi occidentali), Atti della Società di Scienze Naturali e del Museo Civico di Storia Naturale di Milano, 131: 209-219.

Clark R.J., 1969. A collection of Snakes from Greece. British Journal of Herpetology, 4: 45-48.

Giannakopoulos C., Kostopoulou E., Varatsos K.V., Tziotiziou K. \& Plitharas A., 2011. An integrated assessment of Climate Change impacts for Greece in the near future. Regional Environmental Change, 11: 829-843.

Grano M. \& Cattaneo C., 2017. The Balkan Terrapin Mauremys rivulata (Valenciennes in Bory de SaintVincent, 1833) (Testudines Geoemydidae) in the Aegean island of Chalki: native or introduced? Biodiversity Journal, 8: 851-854.

Grillas P., Gauthier N., Yavercovsky N. \& Perennou C., 2004. Mediterranean Temporary Pools, Volume 1, Station biologique de la Tour du Valat, 119 pp.
Grillitsch H. \& Tiedemann F., 1984. Zur Herpetofauna der griechischen Inseln Kea, Spanopoula, Kythnos, Sifnos, Kitriani (Cycladen), Alonissos und Piperi (Nördliche Sporaden). Annalen des Naturhistorische Museum Vienna, 86: 7-28.

Itescu Y., Slavenko A., Schwarz R., Meiri S. \& Pafilis P., 2016. A new island record for Chalcides ocellatus (Forskal, 1775) from Kythnos, Greece. Herpetozoa, 29: 98-100.

Lymberakis P. \& Poulakakis N., 2010. Three continents claiming an archipelago: the evolution of the Aegean`s herpetofaunal diversity. Diversity, Basel, 2010 (2): 233-255. https://doi.org/10.3390/d2020233.

Malkmus R., 1982. Die Bedeutung der Brunnen für den Amphibien-Bestand Portugals. Salamandra, 18: 205217.

Werner F., 1935. Reptilien der Ägäischen Inseln. Sitzungsberichte der Akademie der Wissenschaften, Mathematisch-Naturwissenschaftliche Klasse, Wien, 144: 81-117.

Werner F., 1938. Die Amphibien und Reptilien Griechenlands. Zoologica - Schweizerbardt'sche Verlagshandlung, Stuttgart, 94: 1-114.

Wettstein O., 1953. Herpetologia Aegaea. Sitzungsberichte der Akademie der Wissenschaften, Mathematisch-Naturwissenschaftliche Klasse, Wien, 162: 651-833.

WWF Greece, 2014. Conservation of the Island Wetlands of Greece. WWF Greece, 72 pp. 
. 